\title{
Animal model of methylphenidate's long-term memory-enhancing effects
}

\author{
Stephanie A. Carmack, ${ }^{1}$ Kristin K. Howell, ${ }^{1}$ Kleou Rasaei, ${ }^{1}$ Emilie T. Reas, ${ }^{2}$ and \\ Stephan G. Anagnostaras ${ }^{1,2,3}$ \\ ${ }^{1}$ Molecular Cognition Laboratory, Department of Psychology, University of California, San Diego, California 92093-0109, USA; \\ ${ }^{2}$ Program in Neurosciences, University of California, San Diego, California 92093-0109, USA
}

\begin{abstract}
Methylphenidate (MPH), introduced more than 60 years ago, accounts for two-thirds of current prescriptions for attention deficit hyperactivity disorder (ADHD). Although many studies have modeled MPH's effect on executive function, almost none have directly modeled its effect on long-term memory (LTM), even though improvement in LTM is a critical target of therapeutic intervention in ADHD. We examined the effects of a wide range of doses of MPH $(0.01-10 \mathrm{mg} / \mathrm{kg}$, i.p.) on Pavlovian fear learning, a leading model of memory. MPH's effects were then compared to those of atomoxetine (0.1-10 $\mathrm{mg} / \mathrm{kg}$, i.p.), bupropion (0.5-20 mg/kg, i.p.), and citalopram (0.01-10 mg/ $\mathrm{kg}$, i.p.). At low, clinically relevant doses, MPH enhanced fear memory; at high doses it impaired memory. MPH's memory-enhancing effects were not confounded by its effects on locomotion or anxiety. Further, MPH-induced memory enhancement seemed to require both dopamine and norepinephrine transporter inhibition. Finally, the addictive potential of MPH $(1 \mathrm{mg} / \mathrm{kg}$ and $10 \mathrm{mg} / \mathrm{kg})$ was compared to those of two other psychostimulants, amphetamine $(0.005 \mathrm{mg} / \mathrm{kg}$ and $1.5 \mathrm{mg} / \mathrm{kg})$ and cocaine $(0.15 \mathrm{mg} / \mathrm{kg}$ and $15 \mathrm{mg} /$ $\mathrm{kg}$ ), using a conditioned place preference and behavioral sensitization paradigm. We found that memory-enhancing effects of psychostimulants observed at low doses are readily dissociable from their reinforcing and locomotor activating effects at high doses. Together, our data suggest that fear conditioning will be an especially fruitful platform for modeling the effects of psychostimulants on LTM in drug development.
\end{abstract}

[Supplemental material is available for this article.]

The psychostimulant methylphenidate (MPH) has been used since 1955 as a cognitive enhancer and wake-promoting agent for a variety of disorders (Challman and Lipsky 2000). Over time, it has become the mainstay of treatment for attention deficit hyperactivity disorder (ADHD) as it improves executive control, reduces impulsivity, and improves cognitive function, including learning and memory (O'Toole et al. 1997; Aron et al. 2003; Mehta et al. 2004; Arnsten 2006; Swanson et al. 2011). MPHinduced memory enhancement is often viewed as incidental to improved attention and/or cognitive control (Barkley 1997). Although many studies have modeled MPH's effect on executive function, almost none have directly modeled its effect on longterm memory (LTM) acquisition or retention, per se.

Improvement in LTM is a critical target of therapeutic intervention in ADHD, as ample evidence shows a deficit in LTM in ADHD (Rhodes et al. 2012). Psychostimulants are frequently prescribed to enhance classroom learning and are increasingly sought out by individuals without ADHD for the same reason. Indeed, stimulants also enhance learning in normal populations (Rapoport et al. 1980; Rapoport and Inoff-Germain 2002; Marshall et al. 2010). Thus, the degree to which MPH directly enhances LTM warrants further examination.

Drug development for ADHD would benefit from a simple, efficient animal model of MPH's effects on LTM. We examined the effects of a wide range of doses of MPH on Pavlovian fear learning. In this task, an initially neutral tone conditional stimulus is paired with an aversive foot-shock unconditional stimulus. As

\footnotetext{
${ }^{3}$ Corresponding author

E-mail stephana@ucsd.edu

Article is online at http://www.learnmem.org/cgi/doi/10.1101//m.033613.113.
}

the result of this pairing, the animal comes to fear both the tone and the place of conditioning, a phenomenon known as context conditioning. Tone and context fear memory are used generally to model long-lasting memory (Anagnostaras et al. 1999; Gale et al. 2004).

Fear conditioning has become the leading model of LTM in rats and mice (Anagnostaras et al. 2000, 2001, 2010; Maren 2008). The core neuroanatomy is well studied and distinct from working memory and executive control; acquisition and retention requires the amygdala and hippocampus (Anagnostaras et al. 2001; Gale et al. 2004). The prefrontal cortex (PFC), which has an essential role in working memory and executive function, has a more limited role in fear inhibition and extinction, rather than acquisition (Morgan and LeDoux 1995; Braver et al. 2001).

$\mathrm{MPH}$, a high affinity dopamine transporter (DAT) and norepinephrine transporter (NET) inhibitor (Han and Gu 2006), modulates behavior via increased monoamine neurotransmission (Kuczenski and Segal 1997, 2002; Lazzaro et al. 2010; de Oliveira et al. 2011; Johansen et al. 2011). We also tested diverse monoamine transporter inhibitors that have been used to treat ADHD, atomoxetine (ATM, NET inhibitor), bupropion (BPN, DAT inhibitor), and citalopram (CIT, SERT inhibitor), on fear learning (Fone and Nutt 2005). We further examined MPH's ability to induce locomotor hyperactivity and anxiety as they potentially confound fear conditioning.

\footnotetext{
C 2014 Carmack et al. This article is distributed exclusively by Cold Spring Harbor Laboratory Press for the first 12 months after the full-issue publication date (see http://learnmem.cshlp.org/site/misc/terms.xhtml). After 12 months, it is available under a Creative Commons License (AttributionNonCommercial 3.0 Unported), as described at http://creativecommons. org/licenses/by-nc/3.0/.
} 
We also assessed whether MPH's procognitive and reinforcing effects are dissociable using a conditioned place preference (CPP) and behavioral sensitization paradigm. Behavioral sensitization is a progressive increase in response following repeated administration and models the transition from casual to compulsive use (Robinson and Berridge 1993, 2003). Place preference is the preference for a context previously paired with a drug and is a model of drug seeking. We compared MPH's reinforcing ability with those of amphetamine (AMPH) and cocaine (COC).

In all, we found that memoryenhancing effects of psychostimulants at low doses are readily dissociable from their reinforcing and locomotor activating effects at high doses. We further found that MPH was neither anxiogenic nor anxiolytic. We conclude that MPH's ability to enhance long-term memory appears to be due to a combination of DAT and NET inhibition. We consider whether these results support a direct effect on associativity and memory, rather than as incidental to improved executive function (Barkley 1997).

\section{Results}

\section{MPH dose-effect curve on fear conditioning}

MPH's (0.01-10 mg/kg, i.p.) effects on long-term memory were investigated using Pavlovian fear conditioning. MPH dose-dependently increased locomotor activity during the training baseline $\left(F_{(4,70)}=11.87, P<0.0001\right)$ (Fig. $\left.1 \mathrm{~A}\right)$. Only mice given $10 \mathrm{mg} / \mathrm{kg}$ MPH showed significantly more activity than the saline control group (PLSD, $P<0.0001$; all other $P$ values $>0.3$ ). The 2-sec shock elicited a large increase in velocity, known as the unconditioned response, which did not significantly differ between groups $\left(F_{(3,70)}=0.79, P=0.54\right)$ (Fig. 1B).

MPH dose-dependently modulated freezing during the first 5 min of training (on drug data not depicted) $\left(F_{(4,66)}=6.03, P<\right.$ $0.0001)$. Compared to saline controls $(0 \mathrm{mg} / \mathrm{kg}), 0.01 \mathrm{mg} / \mathrm{kg}$ enhanced freezing $(P<0.005), 10 \mathrm{mg} / \mathrm{kg}$ decreased freezing $(P<$ $0.04)$, and 0.1 and $1 \mathrm{mg} / \mathrm{kg} \mathrm{MPH}$ produced no significant effect $(P$ values $>0.6)$.

There were significant overall group differences in freezing during the immediate memory test $\left(F_{(4,70)}=6.74, P<0.0001\right)$ (data not graphed). Mice given $10 \mathrm{mg} / \mathrm{kg}$ froze $(0.4 \pm 4.2 \%)$ significantly less than saline controls $(22.2 \pm 3.8 \%, P<0.0001)$. However, $10 \mathrm{mg} / \mathrm{kg}$ MPH's ability to stimulate activity likely influenced freezing (Fig. 1A). No other doses affected immediate memory $(0.01,28.9 \pm 4.2 \% ; 0.1,20.1 \pm 4.2 \% ; 1,23.4 \pm 4.5 \% ; P$ values $>0.2$ ).

To determine if MPH influenced long-term contextual memory, mice were returned to the conditioning context $7 \mathrm{~d}$ later off drug. Pretraining MPH dose-dependently modulated memory $\left(F_{(4,70)}=5.46, P=0.001\right)$ (Fig. 1C). Compared to saline controls, $1 \mathrm{mg} / \mathrm{kg}$ enhanced memory $(P=0.027), 10 \mathrm{mg} / \mathrm{kg}$ MPH reduced memory $(P=0.012)$, and 0.01 and $0.1 \mathrm{mg} / \mathrm{kg} \mathrm{MPH}$ failed to influence memory to the context ( $P$ values $>0.5$ ).

Tone memory was assessed $24 \mathrm{~h}$ later (Fig. 1D). Baseline freezing was very low and did not differ between groups (not depicted; $0 \mathrm{mg} / \mathrm{kg}, 4.68 \pm 1.8 \% ; 0.01 \mathrm{mg} / \mathrm{kg}, 8.1 \pm 2.1 \% ; 0.1 \mathrm{mg} / \mathrm{kg}, 14.3 \pm$ $5.3 \% ; 1 \mathrm{mg} / \mathrm{kg}, 9.2 \pm 4.0 \% ; 10 \mathrm{mg} / \mathrm{kg}, 3.5 \pm 0.9 \% ; F_{(4,66)}=1.89$, $P>0.10)$. Again, MPH dose-dependently modulated memory $\left(F_{(4,70)}=2.78, P=0.034\right)$. Both 0.01 and $1 \mathrm{mg} / \mathrm{kg}$ MPH dramatically enhanced memory relative to saline controls ( $P$ values $<0.05$ ). No other doses influenced freezing to the tone ( $P$ values $>0.10$ ).

Overall, we were able to model MPH's dose-dependent memory-enhancing effects using Pavlovian fear conditioning. Clinically relevant doses of MPH given pretraining enhanced long-term contextual and tone memory. In contrast, a high dose of MPH impaired contextual memory.

\section{$\mathrm{MPH}$ and elevated plus maze}

MPH may have modulated anxiety rather than memory acquisition. To control for this possibility, we investigated the effect of 0,1 , and $10 \mathrm{mg} / \mathrm{kg}$ MPH on the elevated plus maze. MPH had no effect on the percent of total time spent in the open vs. enclosed 
$\operatorname{arms}\left(F_{(2,21)}=0.07, P=0.93\right)$ (Fig. 1E). $\mathrm{MPH}$ dose-dependently modulated the number of transitions into the enclosed $\left(F_{(2,21)}=10.8, P=0.001\right)$, but not open arms $\left(F_{(2,21)}=0.6, P=0.56\right)$ (Fig. $\left.1 F\right)$. Mice given $10 \mathrm{mg} / \mathrm{kg} \mathrm{MPH}$ made more transitions into the enclosed arms than the saline control or $1 \mathrm{mg} / \mathrm{kg}$ groups $(P$ values $<0.002)$, which did not differ $(P$ value $>0.99)$. MPH also dosedependently modulated the distance traveled in the enclosed $\left(F_{(2,21)}=9.7\right.$, $P=0.001)$, but not the open arms $\left(F_{(2,21)}=1.1, P=0.36\right)$ (Fig. $\left.1 \mathrm{G}\right)$. Mice given $10 \mathrm{mg} / \mathrm{kg}$ MPH traveled significantly farther than either the saline control or $1 \mathrm{mg} / \mathrm{kg}$ groups ( $P$ values $<0.02$ ), which did not differ $(P$ value $>0.1)$. However, MPH had no effect on the percent of total distance traveled in the open vs. enclosed arms $\left(F_{(2,21)}=0.45\right.$, $P=0.64$ ) (Fig. 1H). These findings indicate that neither 1 nor $10 \mathrm{mg} / \mathrm{kg} \mathrm{MPH}$ altered anxiety.

\section{MPH-induced CPP and sensitization}

We selected the two doses of MPH-1 and $10 \mathrm{mg} / \mathrm{kg}$ - that modulated memory (Fig. 1D) and investigated their addictive potential.

Figure 2A depicts locomotor activity (distance traveled) on training day 1 on the Paired side. Similar to our observations in fear conditioning (Fig. $1 \mathrm{~A})$, the acute response to various doses of $\mathrm{MPH}$ were significantly different $\left(F_{(2,36)}=9.83, \quad P<0.0001\right)$. Compared to saline controls, $10 \mathrm{mg} / \mathrm{kg}$ increased $(P<0.0001)$ and $1 \mathrm{mg} / \mathrm{kg}$ MPH had no effect on locomotor activity $(P>0.7)$.

Figure $2 \mathrm{~B}$ shows locomotor activity across days of training on the Paired side. Significant group differences were observed $\quad\left(F_{(2,36)}=30.0, \quad P<0.0001\right)$. Mice receiving $10 \mathrm{mg} / \mathrm{kg} \mathrm{MPH}$ showed greater locomotor activity than mice receiving saline or $1 \mathrm{mg} / \mathrm{kg}$ $(P$ values $<0.001)$, which did not differ from each other $(P>$ $0.5)$. Sensitization was quantified as the difference in average locomotor response from days 1-7 (Fig. 2C). There were significant group differences $\left(F_{(2,36)}=12.54, P<0.0001\right)$. Neither the saline control nor the $1 \mathrm{mg} / \mathrm{kg} \mathrm{MPH}$ groups showed sensitization; these groups did not differ $(P>0.8)$. Only the mice receiving $10 \mathrm{mg} /$ $\mathrm{kg}$ MPH exhibited sensitization $(P<0.0001)$.

Figure $2 \mathrm{D}$ shows stereotypy during training on the Paired side. Significant group differences were observed $\left(F_{(2,36)}=63.0\right.$, $P<0.0001)$. In terms of average response, mice receiving 10 $\mathrm{mg} / \mathrm{kg} \mathrm{MPH}$ showed greater stereotyped activity than mice receiving saline or $1 \mathrm{mg} / \mathrm{kg}$ ( $P$ values $<0.001)$, which did not differ from each other $(P>0.7)$. As with locomotor activity, there were significant group differences in sensitization $\left(F_{(2,36)}=23.0, P<\right.$ 0.0001 ) (Fig. 2E). Only the mice receiving $10 \mathrm{mg} / \mathrm{kg} \mathrm{MPH}$ sensitized $(P<0.0001)$. No other groups showed sensitization $(P$ values $<0.2$ ).

To test CPP, mice were returned off drug with free access to both sides of the apparatus. Preference was measured as the time spent and distance traveled on the Paired vs. Unpaired sides. There were significant group differences in both time spent $\left(F_{(2,36)}=17.1, \quad P<0.0001\right) \quad$ (Fig. $2 \mathrm{~F}$ ) and distance traveled $\left(F_{(2,36)}=8.87, P<0.001\right.$ ) (Fig. $2 \mathrm{G}$ ). Mice given $10 \mathrm{mg} / \mathrm{kg} \mathrm{MPH}$ showed substantial CPP (time spent, one sample two-tailed $t$-test against hypothesized $\mu=0, t_{(12)}=8.49, P<0.0001$; distance traveled, $\left.t_{(12)}=6.14, P<0.0001\right)$ and greater preference for the Paired side than the other groups (time spent, $P$ values $<0.007$; distance traveled, $P$ values $<0.01$ ). Mice given $1 \mathrm{mg} / \mathrm{kg} \mathrm{MPH}$ showed a very small, but significant preference for the drug-paired side (time spent, $t_{(12)}=2.46, P=0.03$; distance traveled, $t_{(12)}=2.24, P=$ $0.05)$. The saline control group did not show any preference (time spent, $t_{(12)}=1.59, P=0.14$; distance traveled, $t_{(12)}=0.56$, $P=0.59$ ).

To further explore sensitization, mice were challenged with low MPH $(1 \mathrm{mg} / \mathrm{kg})$ and then high MPH $(10 \mathrm{mg} / \mathrm{kg})$ on the Paired side (Fig. 3). There were no overall group differences in locomotor activity $(P=0.112)$ (Fig. 3A, left) following the low MPH challenge, but there were significant group differences in stereotypic counts $\left(F_{(2,36)}=7.95, P=0.001\right)$ (Fig. 3B, left). The group 

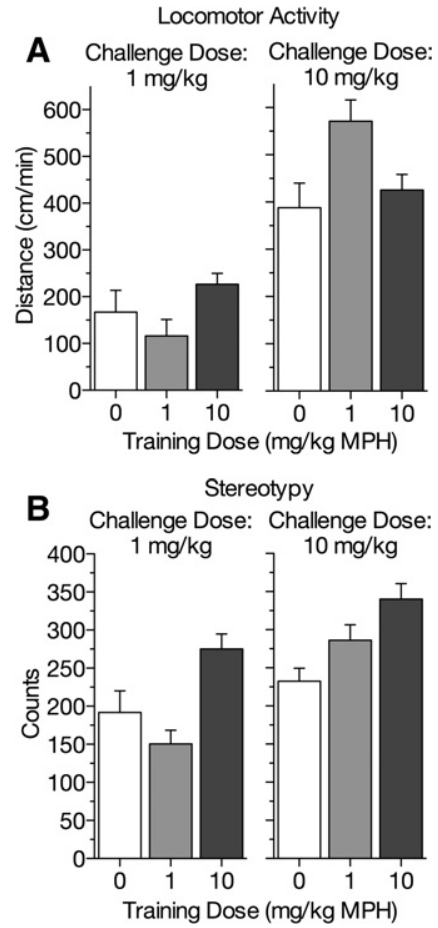

Figure 3. $\mathrm{MPH}$-induced behavioral sensitization. (A) Sensitization of locomotor activity. No group differences in distance traveled were observed following a challenge injection of $1 \mathrm{mg} / \mathrm{kg} \mathrm{MPH}$ (left). In contrast, following a challenge injection of $10 \mathrm{mg} / \mathrm{kg} \mathrm{MPH}$, the group trained with $1 \mathrm{mg} / \mathrm{kg} \mathrm{MPH}$ showed significantly more locomotor activity than the groups previously given saline or $10 \mathrm{mg} / \mathrm{kg} \mathrm{MPH}$, which did not differ from on another (right). (B) Sensitization of stereotyped activity. The group trained with $10 \mathrm{mg} / \mathrm{kg} \mathrm{MPH}$ showed significantly more stereotyped activity in response to a $1 \mathrm{mg} / \mathrm{kg} \mathrm{MPH}$ challenge injection than both the saline control group and the group trained with $1 \mathrm{mg} / \mathrm{kg}$ $\mathrm{MPH}$, which did not differ from one another (left). When challenged with a high dose of MPH $(10 \mathrm{mg} / \mathrm{kg})$, the group trained with $10 \mathrm{mg} /$ $\mathrm{kg} \mathrm{MPH}$ had significantly greater stereotypic counts than the other groups, which did not differ from one another (right). The transition to stereotyped behavior observed only in the group trained with $10 \mathrm{mg} /$ $\mathrm{kg} \mathrm{MPH}$ explains their lack of locomotor sensitization during the high dose MPH challenge test. Each point represents the mean \pm 1 standard error.

trained with $10 \mathrm{mg} / \mathrm{kg}$ MPH showed significantly more stereotyped activity than both the saline control group and the group trained with $1 \mathrm{mg} / \mathrm{kg} \mathrm{MPH}$ ( $P$ values $<0.01)$, which did not differ from each other $(P>0.2)$. Only the group trained with $10 \mathrm{mg} / \mathrm{kg}$ $\mathrm{MPH}$ group showed evidence of a sensitized response to the low MPH challenge.

When challenged with a high dose of MPH (10 mg/kg, i.p.), there were significant group differences in both locomotor $\left(F_{(2,36)}=4.82, P=0.014\right)$ (Fig. $\left.3 \mathrm{~A}\right)$ and stereotypic activity (Fig. $3 \mathrm{~B}$, right; $\left.F_{(2,36)}=7.83, P=0.001\right)$. The group trained with 1 $\mathrm{mg} / \mathrm{kg}$ MPH exhibited some latent sensitization of locomotor activity and had significantly greater locomotor activity than the saline control and $10 \mathrm{mg} / \mathrm{kg}$ MPH groups (Pvalues $<0.03$ ) (Fig. 3A, right). Surprisingly, these groups did not differ in locomotor response $(P=0.55)$. This finding appears to be driven by the 10 $\mathrm{mg} / \mathrm{kg}$ MPH group's transition into stereotyped behavior. Indeed, the $10 \mathrm{mg} / \mathrm{kg}$ MPH group showed significantly greater stereotyped behavior than the other groups ( $P$ values $<0.05)$, which did not differ $(P>0.05)$ (Fig. 3B, right). Both groups trained with $\mathrm{MPH}$ showed some sensitization in response to a high MPH challenge injection.
In sum, $1 \mathrm{mg} / \mathrm{kg}$ MPH had very minimal addictive potential. Repeated administration of $1 \mathrm{mg} / \mathrm{kg}$ MPH did not lead to the development of sensitization. However, challenge with a high dose (10 mg/kg MPH) injection induced some latent locomotor sensitization and there was very slight place preference. In contrast, repeated administration of $10 \mathrm{mg} / \mathrm{kg} \mathrm{MPH}$ induced strong behavioral sensitization and CPP.

\section{AMPH- and COC-induced CPP and sensitization}

We extend these dissociable behavioral findings with MPH to two other psychostimulants, AMPH and COC. Low memoryenhancing doses of AMPH $(0.005 \mathrm{mg} / \mathrm{kg})$ (Wood and Anagnostaras 2009) and COC (0.15 mg/ kg) (Wood et al. 2007) failed to induce behavioral sensitization or CPP. In contrast, high, memoryimpairing doses of AMPH $(1.5 \mathrm{mg} / \mathrm{kg})$ and COC $(15 \mathrm{mg} / \mathrm{kg})$ had significant addictive potential (Fig. 4; see Supplemental Results for details).
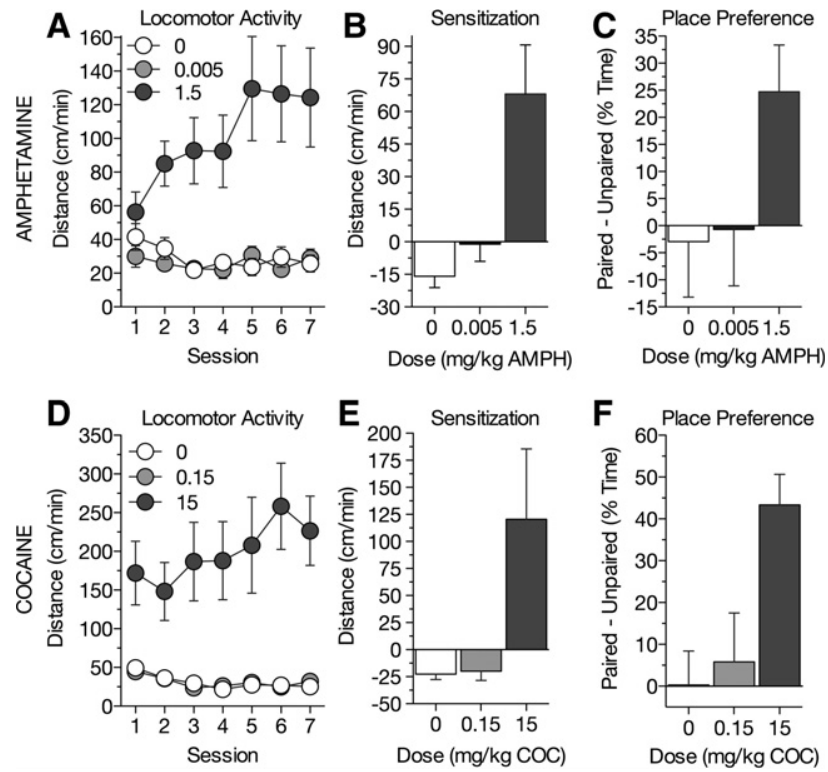

Figure 4. $\mathrm{AMPH}$ and $\mathrm{COC}$-induced addiction-related behaviors. $(A)$ Locomotor activity as an average of each day across the seven training sessions on the drug-paired side. Mice receiving $1.5 \mathrm{mg} / \mathrm{kg} \mathrm{AMPH}$ showed greater locomotor activity than mice receiving saline or $0.005 \mathrm{mg} / \mathrm{kg}$ $\mathrm{AMPH}$, which did not differ from each other. $(B)$ Development of AMPHinduced locomotor sensitization. Sensitization was quantified as the difference in average locomotor response from days $1-7$. Only the mice receiving $1.5 \mathrm{mg} / \mathrm{kg} \mathrm{AMPH}$ exhibited sensitization. Neither the saline control nor the $0.005 \mathrm{mg} / \mathrm{kg}$ AMPH groups showed sensitization. (C) $\mathrm{AMPH}$-induced conditioned place preference. Preference was measured as the difference between the percent of time spent on the Paired side vs. the Unpaired side; positive values indicate preference for the Paired side. Mice that received $1.5 \mathrm{mg} / \mathrm{kg} \mathrm{AMPH}$ showed substantial place preference for Paired side. The saline control group and $0.005 \mathrm{mg} / \mathrm{kg} \mathrm{AMPH}$ groups did not show any preference. $(D)$ Locomotor activity as an average of each day across the seven training sessions on the drug-paired side. Mice receiving $15 \mathrm{mg} / \mathrm{kg}$ COC showed greater locomotor activity than mice receiving saline or $0.15 \mathrm{mg} / \mathrm{kg}$ COC, which did not differ from each other. $(E)$ Development of COC-induced locomotor sensitization. Only the mice receiving $15 \mathrm{mg} / \mathrm{kg}$ COC sensitized. Neither the saline control nor the $0.15 \mathrm{mg} / \mathrm{kg}$ COC group sensitized. (F) COC-induced conditioned place preference. Mice that received $15 \mathrm{mg} / \mathrm{kg} C O C$ showed substantial place preference and greater preference for the Paired side than the other groups. The saline control group and $0.15 \mathrm{mg} / \mathrm{kg} \mathrm{COC}$ groups did not show any preference. Each point represents the mean \pm 1 standard error. 


\section{Neurobiological mechanisms of MPH's dose-dependent behavioral effects}

To investigate the neurobiological mechanisms that underlie MPH's dose-dependent dissociable behavioral effects, we examined the selective transporter inhibitors ATM, BUP, and CIT on fear memory (Supplemental Fig. S1A-I); for a detailed description, see Supplemental Material. Briefly, across the range of doses tested, ATM, BUP, and CIT failed to enhance LTM. In contrast, high doses of BPN and CIT impaired LTM (Supplemental Fig. $\mathrm{S} 1 \mathrm{E}, \mathrm{H}, \mathrm{I})$. Taken together with previous research in our lab demonstrating that low doses of AMPH and COC enhance LTM (Wood et al. 2007; Wood and Anagnostaras 2009), it is interesting to speculate that psychostimulants' ability to enhance LTM acquisition may be related to binding multiple transporter targets, in particular NET and DAT. In Table 1 our results are compared to published affinity studies (Wong et al. 1982; Richelson and Pfenning 1984; Forest Laboratories 2011; GlaxoSmithKline 2013). Within the realm of drugs often prescribed for $\mathrm{ADHD}$, we found that drugs that are highly selective for a single transporter (ATM, CIT) failed to enhance LTM. In contrast, low doses of combined high affinity DAT and NET inhibitors AMPH, COC, and MPH enhanced memory without evidence of reinforcement. At high doses, however, many of the drugs impaired LTM (MPH, AMPH, COC, BUP, and CIT), produced locomotor hyperactivity (MPH, AMPH, COC), and showed evidence of reinforcement and addiction $(\mathrm{AMPH}$, $\mathrm{COC}, \mathrm{MPH})$.

\section{Discussion}

More than 65 years after its introduction, MPH is the first-line treatment for ADHD (Spencer et al. 1996; Barkley 1998). MPH can have serious side effects, however, including growth retardation, nausea, insomnia, anxiety, tics, and cardiovascular risk (McNeil Pediatrics 2008), suggesting need for further develop- ment of psychostimulants. Though progress has been made in ADHD drug delivery, recently approved therapeutics, such as atomoxetine and guanfacine, are inferior in clinical efficacy to $\mathrm{MPH}$ or $\mathrm{AMPH}$, despite their ability to reduce inattention and impulsivity (Wigal et al. 2005; Faraone et al. 2007; Newcorn et al. 2008).

Most clinical efficacy studies only report inattention/hyperactivity-impulsivity measures (ADHD IV) (Dittmann et al. 2013) and clinical global impression (CGI) (Setyawan et al. 2013). These studies do not assess efficacy in improving LTM. Rather, they focus on improvements in problem classroom behaviors even though a growing body of evidence shows an impairment of LTM in ADHD (Rhodes et al. 2012).

MPH's clinical efficacy is generally modeled using attention or cognitive control tasks, such as attentional set-shift, stopsignal, and five-choice serial reaction time (Puumala et al. 1996; Robbins 2002; Arnsten and Dudley 2005; Eagle et al. 2007; Berridge et al. 2012; Humby et al. 2013). However, these models do not assess LTM and are difficult to implement in high throughput drug development as they are complex, sometimes require extensive training, and often are in monkeys. Drug development will benefit from the addition of this simple, efficient mouse model of MPH's effects on LTM because of cost, the widespread use of mice preclinically, and the widely available genetic tools in mice.

At $1 \mathrm{mg} / \mathrm{kg}$, MPH enhanced the acquisition of both contextual and tone memory. Even lower doses $(0.01-0.1 \mathrm{mg} / \mathrm{kg})$ dramatically enhanced tone memory. This finding is consistent with previous research showing that low doses of AMPH, modafinil, and COC enhance fear memory (Wood et al. 2007; Shuman et al. 2009; Wood and Anagnostaras 2009). Further, MPH modulates fear memory independent of its effects on locomotor activity or anxiety.

Pavlovian fear conditioning has become especially useful as an experimental model in psychiatric research because of its simplicity (LeDoux 1998; Maren 2008; Mahan and Ressler 2012):

Table 1. Behavioral effects and binding affinities of methylphenidate, amphetamine, cocaine, atomoxetine, bupropion, and citalopram

\begin{tabular}{|c|c|c|c|c|c|c|c|}
\hline \multirow[b]{2}{*}{ Drug } & \multirow[b]{2}{*}{ Dose } & \multicolumn{3}{|c|}{ Behavior } & \multicolumn{3}{|c|}{ Binding affinity $\left(K_{i}\right)^{\mathrm{a}}$} \\
\hline & & Locomotion $^{\mathbf{b}}$ & Reinforcement $^{c}$ & Memory $^{\mathrm{d}}$ & DAT (nM) & NET (nM) & SERT (nM) \\
\hline \multirow[t]{2}{*}{ Methylphenidate $^{\mathrm{e}}$} & Low & - & - & $\uparrow$ & 160 & 40 & 22,000 \\
\hline & High & $\uparrow$ & $\uparrow$ & $\downarrow$ & & & \\
\hline \multirow[t]{2}{*}{ D-Amphetamine ${ }^{f}$} & Low & - & - & $\uparrow$ & 82 & 50 & 1840 \\
\hline & High & $\uparrow$ & $\uparrow$ & $\downarrow$ & & & \\
\hline \multirow[t]{2}{*}{ Cocaine $^{\mathrm{g}}$} & Low & $\uparrow$ & - & $\uparrow$ & 270 & 155 & 180 \\
\hline & High & $\uparrow$ & $\uparrow$ & $\downarrow$ & & & \\
\hline \multirow{2}{*}{ Atomoxetine $\mathrm{h}^{\mathrm{h}}$} & Low & - & - & - & 1800 & 1.9 & 750 \\
\hline & High & $\downarrow$ & - & - & & & \\
\hline \multirow[t]{2}{*}{ Bupropion ${ }^{i}$} & Low & - & - & - & 630 & 2300 & 15,600 \\
\hline & High & $\uparrow$ & $?$ & $\downarrow$ & & & \\
\hline \multirow[t]{2}{*}{ Citalopram $^{\mathrm{j}}$} & Low & - & - & - & 28,000 & 4000 & 1.3 \\
\hline & High & - & ? & $\downarrow$ & & & \\
\hline
\end{tabular}

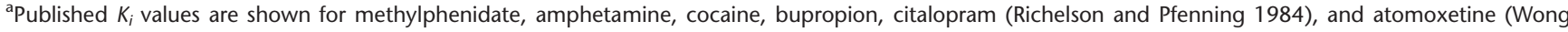
et al. 1982) in the rat brain. Please note low $K_{i}$ values indicate high affinity.

${ }^{\mathrm{b}}(\uparrow)$ The drug elevates locomotor activity at the specified dose; $(\downarrow)$ the drug decreases locomotor activity; $(-)$ no effect.

${ }^{c}(\uparrow)$ The drug increases addictive potential at the specified dose; $(-)$ no known addictive potential; (?) the drug effect is not known.

${ }^{d}(\uparrow)$ The drug enhances memory at the specified dose; $(\downarrow)$ the drug impairs memory; $(-)$ no effect.

'Methylphenidate's locomotor and reinforcing effects are depicted in Figures 1A, 2, and 3; its effects on memory are shown in Figure 1, C and D.

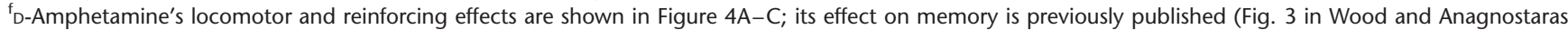
2009).

${ }^{9}$ Cocaine's locomotor and reinforcing effects are depicted in Figure 4D-F; its effect on memory is previously published (Fig. 3 in Wood et al. 2007).

${ }^{\mathrm{h}}$ Atomoxetine's locomotor and reinforcing effects are shown in Supplemental Figures S1A and S2; its effects on memory are shown in Supplemental Figure S1, $B$ and $C$.

'Bupropion's locomotor and reinforcing effects are reported in Wellbutrin's FDA approved labeling (GlaxoSmithKline 2013); its effects on memory are shown in Supplemental Figure S1, E and F.

${ }^{j}$ Citalopram's locomotor and reinforcing effects are reported in Celexa's FDA approved labeling (Forest Laboratories 2011); its effects on memory are shown in Supplemental Figure S1, $\mathrm{H}$ and I. 
a single tone-shock pairing can result in a long-lasting memory (Fig. 1). Additionally, its established neural circuitry is similar between rodents and humans (LeDoux 1998; Delgado et al. 2006). $\mathrm{MPH}$, a high affinity DAT and NET inhibitor (Han and Gu 2006), likely enhances memory acquisition by increasing monoamine neurotransmission (Kuczenski and Segal 1997, 2002; Lazzaro et al. 2010; de Oliveira et al. 2011; Johansen et al. 2011). We tested CIT, ATM, and BPN on fear learning to investigate the consequences of selectively blocking SERT, NET, and DAT. Reviewing these very generally, one is left with the impression that considerable affinity for both NET and DAT may be required for the cognitive enhancing effects of psychostimulants (Table 1; Wong et al. 1982; Richelson and Pfenning 1984; Forest Laboratories 2011; GlaxoSmithKline 2013).

MPH's effects on memory acquisition are often construed to be the exclusive result of improved attention or executive control (Barkley 1997). This interpretation is difficult to reconcile with our observation that MPH dramatically enhances long-term tone memory (Fig. 1D). The attentional demands in tone fear conditioning are modest at best; a very loud tone is followed by an even more attention-grabbing, inescapable foot shock. Furthermore, although working memory is heavily conflated with executive control, decades of evidence suggest that the core neurobiology of LTM is distinct from that of executive control (Morgan and LeDoux 1995; Braver et al. 2001). This suggests that MPH may also directly influence core associative mechanisms such as long-term potentiation (LTP).

Substantial evidence does exist that MPH acts on cellular substrates implicated in LTM; for example, MPH enhances long-term potentiation and depression (Dommett et al. 2008; Tye et al. 2010). Recently, acute administration of MPH in rats has been shown to facilitate plasticity in the amygdala via an increase in AMPA receptor-mediated currents following a cue-reward learning task (Tye et al. 2010). MPH also increases hippocampal norepinephrine in vivo (Kuczenski and Segal 2002) and such changes are known to influence synaptic plasticity (Akirav and RichterLevin 2002). Thus, the potential that MPH directly improves learning or associability directly warrants further investigation. Ultimately, improved classroom learning will be demonstrated by improvements in LTM, such as on exams.

We further demonstrate that MPH's memory-enhancing effect at low doses is dissociable from its reinforcing effects induced by high doses. Most animal studies have used doses 2-40 times higher than the clinically relevant dose in an effort to model addiction (Gainetdinov et al. 1999; Kuczenski and Segal 2002; Abraham et al. 2012). We have advocated using a one-to-one dosing scheme unless specific evidence warrants using a different dose in mice (Wood et al. 2007; Shuman et al. 2009; Wood and Anagnostaras 2009). No evidence suggests that appropriate rodent dosing should be 40 times higher than human dosing. MPH is available in a variety of time-released preparations, but is typically prescribed around $0.5-1 \mathrm{mg} / \mathrm{kg}$, and is not meant to exceed $2 \mathrm{mg}$ / $\mathrm{kg} /$ day (McNeil Pediatrics 2008). The memory-enhancing doses that we observed (0.01-1 mg/kg) accord well with and are on the same order of magnitude as prescribed doses.

The memory-enhancing dose (1 mg/kg MPH) showed little evidence of reinforcement. In contrast, $10 \mathrm{mg} / \mathrm{kg} \mathrm{MPH}$ not only produced sensitization, place preference, and a marked stimulating effect, but it also impaired memory. This dissociation is supported by our observation that memory-enhancing doses of AMPH $(0.005 \mathrm{mg} / \mathrm{kg})$ and COC $(1.5 \mathrm{mg} / \mathrm{kg})$ also showed little evidence of reinforcement, while high, addictive, doses impaired memory (Fig. 4). Together, these results substantiate the view that psychostimulant dosage explains the "paradox" of cognitive enhancements in patient populations and cognitive deficits in addicts (Rapoport et al. 1980; Ellinwood et al. 1998; Rapoport and
Inoff-Germain 2002; Berridge and Devilbiss 2011; Wood et al. 2013). As dosage dramatically dissociates psychostimulants' procognitive and reinforcing effects, it is likely that one can develop an MPH-like drug, which retains all of MPH's procognitive effects, but lacks any reinforcing effects. Though, to date, such efforts have been limited.

Overall, we found a clear long-term enhancement of memory by $\mathrm{MPH}$ at doses similar to those prescribed for ADHD; these memory-enhancing effects were not confounded by effects on locomotion or anxiety and were readily dissociable from the reinforcing effects seen at high doses. Together, our data suggest that fear conditioning will be an especially fruitful platform for modeling the effects of psychostimulants on LTM in drug development.

\section{Materials and Methods}

\section{Subjects}

We used 380 hybrid C57BL/6Jx129S1/SvImJ (Jackson Labs) group-housed mice, at least 10 wk old before testing. The vivarium was on a 14:10-h light-dark schedule and testing occurred during the light phase. All procedures were approved by the UCSD IACUC and compliant with the NRC Guide.

\section{Drugs}

Dosing was by salt weight and the vehicle was always $0.9 \%$ saline. Methylphenidate $\mathrm{HCl}$ (Sigma-Aldrich) was given in $0.01,0.1,1$, or $10 \mathrm{mg} / \mathrm{kg}$. Atomoxetine $\mathrm{HCl}$ (Tata) was given in $0.01,0.5,1$, or 10 $\mathrm{mg} / \mathrm{kg}$. Bupropion $\mathrm{HCl}$ (Biomol) was given in $0.5,5,10$, or $20 \mathrm{mg} /$ kg. Citalopram $\mathrm{HBr}$ (Enzo) was given in $0.01,0.1$, 1, or $10 \mathrm{mg} / \mathrm{kg}$. D-Amphetamine hemisulfate (Sigma) was given in 0.005 or 1.5 $\mathrm{mg} / \mathrm{kg}$. Cocaine $\mathrm{HCl}$ (Sigma) was given in 0.15 or $15 \mathrm{mg} / \mathrm{kg}$. All injections were given intraperitoneally (i.p.), $10 \mathrm{~mL} / \mathrm{kg}$.

\section{Fear conditioning}

Eight mice were tested concurrently in individual conditioning chambers. The VideoFreeze system (Med Associates) was used as described previously (Anagnostaras et al. 2010; Carmack et al. 2010, 2013); see Supplemental Methods for details of all drugs tested. For MPH experiments mice were injected $30 \mathrm{~min}$ before training. Mice were randomly assigned to groups by dose of MPH administered: 0 (saline control, $n=17), 0.01(n=14), 0.1$ $(n=14), 1(n=12)$, or $10 \mathrm{mg} / \mathrm{kg}(n=14)$.

Training began with a 3 -min baseline, followed by one toneshock pairing, consisting of a 30 -sec tone $(2.8 \mathrm{kHz}, 85 \mathrm{dBA})$ that co-terminated with a 2-sec scrambled, AC foot shock $(0.75 \mathrm{~mA}$, RMS). Mice were in the chambers for a total of $10 \mathrm{~min}$ (Wood and Anagnostaras 2011). Freezing behavior and locomotor activity were recorded (Anagnostaras et al. 2000; Carmack et al. 2010).

Mice were returned to the training context, without drug, $7 \mathrm{~d}$ later. Freezing was scored for 5 min to measure context fear. Mice were placed in an alternate context $24 \mathrm{~h}$ later, also off drug, to measure tone fear. The training context was altered for tone testing trials: white acrylic sheets were placed over the grid floors and a black plastic, triangular teepee was placed inside each box. Only near-infrared light was used, creating a dark environment. The chambers were cleaned and scented with a $5 \%$ vinegar solution. Tone testing consisted of a 2-min baseline, followed by a 3-min tone $(2.8 \mathrm{kHz}, 85 \mathrm{dBA})$.

\section{Elevated plus maze}

The plus maze (MED Associates) had two open and two enclosed arms $(6.5 \mathrm{~cm} \times 36 \mathrm{~cm}$ each) joined at a center hub $(6.5 \mathrm{~cm} \times 6.5$ $\mathrm{cm}$ ) elevated $74 \mathrm{~cm}$ from the ground. Testing lasted $5 \mathrm{~min}$ in dim light. The floor of the maze had near infrared backlighting invisible to the mice to provide video contrast. Mice were tracked using a camera and video tracking software (Panlab Smart 3.0, Harvard Apparatus). Mice were given 0 (saline control, $n=8$ ), 
$1(n=8)$, or $10 \mathrm{mg} / \mathrm{kg} \mathrm{MPH}(n=8) 30 \mathrm{~min}$ prior to testing. Time spent, distance traveled, and transitions (head and shoulder entries) between each section were recorded.

\section{Conditioned place preference (CPP) and behavioral sensitization}

Eight mice were tested concurrently in individual CPP chambers $(43 \times 43 \times 31 \mathrm{~cm}$, Med Associates $)$ as previously described (Carmack et al. 2013). Each chamber consisted of two distinct (visual, tactile, and odor cues) sides bisected by an opaque wall with a removable insert. Activity Monitor software (Med Associates) used infrared beams to detect mouse position and to derive locomotor activity (distance) and stereotypy (counts). Mice were habituated to the apparatus for $30 \mathrm{~min}$ per side per day for $2 \mathrm{~d}$ prior to training.

On each of seven daily CPP training sessions, mice were placed into each side of the apparatus for 15 min per side per day. All mice were first given saline prior to placement into the first side (Unpaired). Then, all mice were given drug prior to placement into the second side (Paired). The compartments were counterbalanced. For MPH experiments, mice were assigned to one of three drug groups ( $n=13$ /group): 0 (saline control), 1 (low dose), or 10 (high dose) $\mathrm{mg} / \mathrm{kg}$ MPH. These doses of MPH maximally enhanced and impaired fear memory in the fear conditioning experiment (Fig. 1C).

Twenty-four hours after the final training session, mice were tested off drug for CPP. The insert was removed and subjects were allowed access to both sides of the chamber for $15 \mathrm{~min}$.

To measure the development of sensitization, distance traveled and stereotyped activity were recorded during training on the Paired side. Development of sensitization was calculated as the difference between day 1 (acute) and day 7 (sensitized) response. Additionally, all mice received two challenge tests: one with a low dose $(1 \mathrm{mg} / \mathrm{kg} \mathrm{MPH}) 48 \mathrm{~h}$ after training, and one with a high dose $(10 \mathrm{mg} / \mathrm{kg} \mathrm{MPH}) 72 \mathrm{~h}$ after training. For both tests, all mice were injected with drug and immediately placed into the Paired side for $45 \mathrm{~min}$

AMPH's and COC's ability to induce CPP and sensitization at low $(0.005$ and $0.15 \mathrm{mg} / \mathrm{kg})$ and high doses $(1.5$ and $15 \mathrm{mg} / \mathrm{kg})$ were also investigated using the above protocol. These doses maximally enhanced or impaired memory in previously published work (Wood et al. 2007; Wood and Anagnostaras 2009); see Supplemental Methods for more details.

\section{Statistical analyses}

Data were analyzed using multivariate or univariate analyses of variance (ANOVAs). Post-hoc comparisons were performed following significant omnibus comparisons using Fisher's protected least significant difference tests. The level of significance was $P \leq$ 0.05 . We found no evidence of sex-related differences in any measures $(P$ values $>0.2$ ), so male and female data were collapsed.

\section{Acknowledgments}

We gratefully acknowledge Leila Davis, Alexandra Cifelli, Monette Leyva, Vanessa Wu, Sarah D'Angelo, Carina Block, and Erin McNalley for technical assistance. We also thank Antonio Mora, Roy Jungay and Gilberto Sanchez for excellent animal care. We thank Jordan Comins and Liz Harrison for helpful comments on an earlier version of this manuscript. These studies were supported by NIH grant DA020041 (S.G.A.), Hellman Fellowship (S.G.A.), NSF Graduate Research Fellowship (K.K.H.), and UCSD Chancellor's Interdisciplinary Collaboratories Grant (S.A.C., E.T.R.).

\section{References}

Abraham AD, Cunningham CL, Lattal KM. 2012. Methylphenidate enhances extinction of contextual fear. Learn Mem 19: 67-72.

Akirav I, Richter-Levin G. 2002. Mechanisms of amygdala modulation of hippocampal plasticity. J Neurosci 22: 9912-9921.
Anagnostaras SG, Maren S, Fanselow MS. 1999. Temporally graded retrograde amnesia of contextual fear after hippocampal damage in rats: Within-subjects examination. J Neurosci 19: 1106-1114.

Anagnostaras SG, Josselyn SA, Frankland PW, Silva AJ. 2000. Computer-assisted behavioral assessment of Pavlovian fear conditioning in mice. Learn Mem 7: 58-72.

Anagnostaras SG, Gale GD, Fanselow MS. 2001. Hippocampus and contextual fear conditioning: Recent controversies and advances. Hippocampus 11: $8-17$.

Anagnostaras SG, Wood SC, Shuman T, Cai DJ, Leduc AD, Zurn KR, Zurn JB, Sage JR, Herrera GM. 2010. Automated assessment of pavlovian conditioned freezing and shock reactivity in mice using the video freeze system. Front Behav Neurosci 4: 1-11.

Arnsten AF. 2006. Stimulants: Therapeutic actions in ADHD. Neuropsychopharmacology 31: 2376-2383.

Arnsten AF, Dudley AG. 2005. Methylphenidate improves prefrontal cortical cognitive function through $\alpha 2$ adrenoceptor and dopamine D1 receptor actions: Relevance to therapeutic effects in attention deficit hyperactivity disorder. Behav Brain Funct 1: 2-10.

Aron AR, Dowson JH, Sahakian BJ, Robbins TW. 2003. Methylphenidate improves response inhibition in adults with attention-deficit/ hyperactivity disorder. Biol Psychiatry 54: 1465-1468.

Barkley RA. 1997. Behavioral inhibition, sustained attention, and executive functions: Constructing a unifying theory of ADHD. Psychol Bull 121: $65-94$

Barkley RA. 1998. Attention deficit hyperactivity disorder: A handbook for diagnosis and treatment. Guilford Press, New York.

Berridge CW, Devilbiss DM. 2011. Psychostimulants as cognitive enhancers: The prefrontal cortex, catecholamines, and attention-deficit/hyperactivity disorder. Biol Psychiatry 69: e101-e111.

Berridge CW, Shumsky JS, Andrzejewski ME, McGaughy JA, Spencer RC, Devilbiss DM, Waterhouse BD. 2012. Differential sensitivity to psychostimulants across prefrontal cognitive tasks: Differential involvement of noradrenergic $\alpha 1$ - and $\alpha 2$-receptors. Biol Psychiatry 71: $467-473$.

Braver TS, Barch DM, Kelley WM, Buckner RL, Cohen NJ, Miezin FM, Snyder AZ, Ollinger JM, Akbudak E, Conturo TE, et al. 2001. Direct comparison of prefrontal cortex regions engaged by working and long-term memory tasks. NeuroImage 14: 48-59.

Carmack SA, Wood SC, Anagnostaras SG. 2010. Amphetamine and extinction of cued fear. Neurosci Lett 468: 18-22.

Carmack SA, Kim JS, Sage JR, Thomas AW, Skillicorn KN, Anagnostaras SG. 2013. The competitive NMDA receptor antagonist CPP disrupts cocaine-induced conditioned place preference, but spares behavioral sensitization. Behav Brain Res 239: 155-163.

Challman TD, Lipsky JJ. 2000. Methylphenidate: Its pharmacology and uses. Mayo Clin Proc 75: 711-721.

Delgado MR, Olsson A, Phelps EA. 2006. Extending animal models of fear conditioning to humans. Biol Psychol 73: 39-48.

de Oliveira AR, Reimer AE, de Macedo CEA, de Carvalho MC, Silva MA Brandão ML. 2011. Conditioned fear is modulated by D2 receptor pathway connecting the ventral tegmental area and basolateral amygdala. Neurobiol Learn Mem 95: 37-45.

Dittmann RW, Cardo E, Nagy P, Anderson CS, Bloomfield R, Caballero B, Higgins N, Hodgkins P, Lyne A, Civil R, et al. 2013. Efficacy and safety of lisdexamfetamine dimesylate and atomoxetine in the treatment of attention-deficit/hyperactivity disorder: a head-to-head, randomized, double-blind, phase IIIb study. CNS Drugs doi: 10.1007/s40263-0130104-8.

Dommett EJ, Henderson EL, Westwell MS, Greenfield SA. 2008. Methylphenidate amplifies long-term plasticity in the hippocampus via noradrenergic mechanisms. Learn Mem 15: 580-586.

Eagle DM, Tufft MR, Goodchild HL, Robbins TW. 2007. Differential effects of modafinil and methylphenidate on stop-signal reaction time task performance in the rat, and interactions with the dopamine receptor antagonist cis-flupenthixol. Psychopharmacology 192: 193-206.

Ellinwood EH, King G, Lee T. 1998. Chronic amphetamine use and abuse. In Psychopharmacology: The fourth generation of progress (ed. Watson SJ), http://www.acnp.org/g4/gn401000166/ch162.htm. Lippincott, Williams \& Wilkins, Philadelphia, PA.

Faraone SV, Wigal SB, Hodgkins P. 2007. Forecasting three-month outcomes in a laboratory school comparison of mixed amphetamine salts extended release (Adderall XR) and atomoxetine (Strattera) in school-aged children with ADHD. J Atten Disord 11: 74-82.

Fone KCF, Nutt DJ. 2005. Stimulants: Use and abuse in the treatment of attention deficit hyperactivity disorder. Curr Opin Pharmacol 5: 87-93.

Forest Laboratories. 2011. Celexa: Full prescribing information. http://www.accessdata.fda.gov/drugsatfda_docs/label/2011/ 020822s038s040,021046s016s017lbl.pdf.

Gainetdinov RR, Wetsel WC, Jones SR, Levin ED, Jaber M, Caron MG. 1999. Role of serotonin in the paradoxical calming effect of psychostimulants on hyperactivity. Science 283: 397-401. 
Gale GD, Anagnostaras SG, Godsil BP, Mitchell S, Nozawa T, Sage JR, Wiltgen B, Fanselow MS. 2004. Role of the basolateral amygdala in the storage of fear memories across the adult lifetime of rats. J Neurosci 24: $3810-3815$.

GlaxoSmithKline. 2013. Wellbutrin: Full prescribing information. http://www.accessdata.fda.gov/drugsatfda_docs/label/2011/ 018644s043lbl.pdf.

Han DD, Gu HH. 2006. Comparison of the monoamine transporters from human and mouse in their sensitivities to psychostimulant drugs. BMC Pharmacol 6: 6.

Humby T, Eddy JB, Good MA, Reichelt AC, Wilkinson LS. 2013. A novel translational assay of response inhibition and impulsivity: Effects of prefrontal cortex lesions, drugs used in ADHD, and serotonin 2C receptor antagonism. Neuropsychopharmacology 38: $2150-2159$.

Johansen JP, Cain CK, Ostroff LE, LeDoux JE. 2011. Molecular mechanisms of fear learning and memory. Cell 147: 509-524.

Kuczenski R, Segal DS. 1997. Effects of methylphenidate on extracellular dopamine, serotonin, and norepinephrine: Comparison with amphetamine. J Neurochem 68: 2032-2037.

Kuczenski R, Segal DS. 2002. Exposure of adolescent rats to oral methylphenidate: Preferential effects on extracellular norepinephrine and absence of sensitization and cross-sensitization to methamphetamine. J Neurosci 22: 7264-7271.

Lazzaro SC, Hou M, Cunha C, Ledoux JE, Cain CK. 2010. Antagonism of lateral amygdala $\alpha 1$-adrenergic receptors facilitates fear conditioning and long-term potentiation. Learn Mem 17: 489-493.

LeDoux J. 1998. Fear and the brain: Where have we been, and where are we going? Biol Psychiatry 44: 1229-1238.

Mahan AL, Ressler KJ. 2012. Fear conditioning, synaptic plasticity and the amygdala: Implications for posttraumatic stress disorder. Trends Neurosci 35: 24-35.

Maren S. 2008. Pavlovian fear conditioning as a behavioral assay for hippocampus and amygdala function: Cautions and caveats. Eur J Neurosci 28: 1661-1666.

Marshall P, Schroeder R, O’Brien J, Fischer R, Ries A, Blesi B, Barker J. 2010. Effectiveness of symptom validity measures in identifying cognitive and behavioral symptom exaggeration in adult attention deficit hyperactivity disorder. Clin Neuropsychol 24: 1204-1237.

McNeil Pediatrics. 2008. Concerta: Full prescribing information. http://www.accessdata.fda.gov/drugsatfda_docs/label/2008/ 021121s015s017lbl.pdf.

Mehta MA, Goodyer IM, Sahakian BJ. 2004. Methylphenidate improves working memory and set-shifting in $\mathrm{AD} / \mathrm{HD}$ : Relationships to baseline memory capacity. J Child Psychol Psychiatry 45: 293-305.

Morgan MA, LeDoux JE. 1995. Differential contribution of dorsal and ventral medial prefrontal cortex to the acquisition and extinction of conditioned fear in rats. Behav Neurosci 109: 681-688.

Newcorn JH, Kratochvil CJ, Allen AJ, Casat CD, Ruff DD, Michelson D. 2008. Atomoxetine and osmotically released methylphenidate for the treatment of attention deficit hyperactivity disorder: acute comparison and differential response. Am J Psychiatry 165: 721-730.

O'Toole K, Abramowitz A, Morris R, Dulcan M. 1997. Effects of methylphenidate on attention and nonverbal learning in children with attention-deficit hyperactivity disorder. J Am Acad Child Adolesc Psychiatry 36: 531-538.

Puumala T, Ruotsalainen S, Jäkälä P, Koivisto E, Riekkinen P, Sirviö J. 1996. Behavioral and pharmacological studies on the validation of a new animal model for attention deficit hyperactivity disorder. Neurobiol Learn Mem 66: 198-211.
Rapoport JL, Inoff-Germain G. 2002. Responses to methylphenidate in attention-deficit/hyperactivity disorder and normal children: Update 2002. J Atten Disord 6: S57-S60.

Rapoport JL, Buchsbaum MS, Weingartner H, Zahn TP, Ludlow C, Mikkelsen EJ. 1980. Dextroamphetamine: It's cognitive and behavioral effects in normal and hyperactive boys and normal men. Arch Gen Psychiatry 37: 933-943.

Rhodes SM, Park J, Seth S, Coghill DR. 2012. A comprehensive investigation of memory impairment in attention deficit hyperactivity disorder and oppositional defiant disorder. J Child Psychol Psychiatry 53: 128-137.

Richelson E, Pfenning M. 1984. Blockade by antidepressants and related compounds of biogenic amine uptake into rat brain synaptosomes: Most antidepressants selectively block norepinephrine uptake. Eur J Pharmacol 104: 277-286.

Robbins TW. 2002. The 5-choice serial reaction time task: Behavioural pharmacology and functional neurochemistry. Psychopharmacology 163: $362-380$.

Robinson TE, Berridge KC. 1993. The neural basis of drug craving: An incentive-sensitization theory of addiction. Brain Res Rev 18: 247-291.

Robinson TE, Berridge KC. 2003. Addiction. Ann Rev Psychol 54: 25-53.

Setyawan J, Guerin A, Hodgkins P, Gauthier G, Cloutier M, Wu E, Erder MH. 2013. Treatment persistence in attention deficit hyperactivity disorder: A retrospective analysis of patients initiated on lisdexamfetamine vs other medications. J Med Econ 16: 1275-1289.

Shuman T, Wood SC, Anagnostaras SG. 2009. Modafinil and memory: Effects of modafinil on Morris water maze learning and Pavlovian fear conditioning. Behav Neurosci 123: 257-266.

Spencer T, Biederman J, Wilens T, Harding M, O'Donnell D, Griffin S. 1996. Pharmacotherapy of attention-deficit hyperactivity disorder across the life cycle. J Am Acad Child Adolesc Psychiatry 35: 409-432.

Swanson J, Baler RD, Volkow ND. 2011. Understanding the effects of stimulant medications on cognition in individuals with attention-deficit hyperactivity disorder: A decade of progress. Neuropsychopharmacology 36: 207-226.

Tye KM, Tye LD, Cone JJ, Hekkelman EF, Janak PH, Bonci A. 2010. Methylphenidate facilitates learning-induced amygdala plasticity. Nat Neurosci 13: $475-481$.

Wigal SB, McGough JJ, McCracken JT, Biederman J, Spencer TJ, Posner KL, Wigal TL, Kollins SH, Clark TM, Mays DA, et al. 2005. A laboratory school comparison of mixed amphetamine salts extended release (Adderall XR) and atomoxetine (Strattera) in school-aged children with attention deficit/hyperactivity disorder. J Atten Disord 9: 275-289.

Wong DT, Threlkeld PG, Best KL, Bymaster FP. 1982. A new inhibitor of norepinephrine uptake devoid of affinity for receptors in rat brain. J Pharmacol Exp Ther 222: 61-65.

Wood SC, Anagnostaras SG. 2009. Memory and psychostimulants: Modulation of Pavlovian fear conditioning by amphetamine in C57BL/ 6 mice. Psychopharmacology 202: 197-206.

Wood SC, Anagnostaras SG. 2011. Interdependence of measures in pavlovian conditioned freezing. Neurosci Lett 505: 134-139.

Wood SC, Fay J, Sage JR, Anagnostaras SG. 2007. Cocaine and Pavlovian fear conditioning: Dose-effect analysis. Behav Brain Res 176: 244-250.

Wood SC, Sage JR, Shuman T, Anagnostaras SG. 2013. Psychostimulants and cognition: A continuum of behavioral and cognitive activation. Pharmacol Rev (in press).

Received October 15, 2013; accepted in revised form October 28, 2013. 


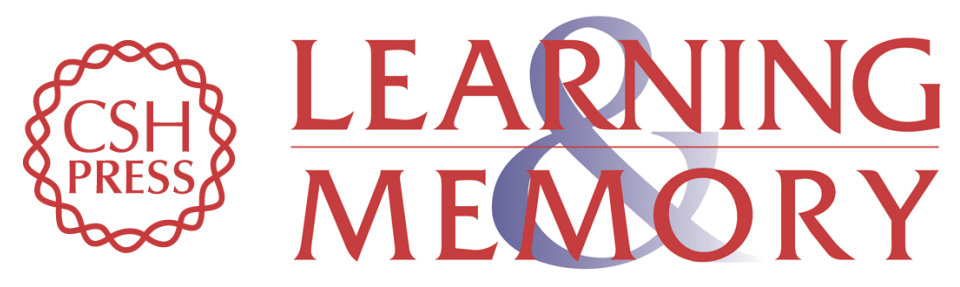

\section{Animal model of methylphenidate's long-term memory-enhancing effects}

Stephanie A. Carmack, Kristin K. Howell, Kleou Rasaei, et al.

Learn. Mem. 2014, 21:

Access the most recent version at doi:10.1101/Im.033613.113

\section{Supplemental http://learnmem.cshlp.org/content/suppl/2014/01/10/21.2.82.DC1 Material}

References This article cites 57 articles, 10 of which can be accessed free at: http://learnmem.cshlp.org/content/21/2/82.full.html\#ref-list-1

Creative This article is distributed exclusively by Cold Spring Harbor Laboratory Press for the Commons first 12 months after the full-issue publication date (see

License http://learnmem.cshlp.org/site/misc/terms.xhtml). After 12 months, it is available under a Creative Commons License (Attribution-NonCommercial 3.0 Unported), as described at http://creativecommons.org/licenses/by-nc/3.0/.

Email Alerting Receive free email alerts when new articles cite this article - sign up in the box at the Service top right corner of the article or click here. 